\title{
Accuracy of Analytical Models to Predict Primary and Secondary System Response in Seismically Isolated Buildings
}

Cengiz Ipek ( $\nabla$ cengiz.ipek@medeniyet.edu.tr)

"Istanbul Medeniyet Universitesi"

Eric D. Wolff

University of California San Diego Geisel Library: University of California San Diego

Michael C. Constantinou

SUNY Buffalo: University at Buffalo

\section{Research Article}

Keywords: Seismic isolation, Analytical models, Primary systems, Secondary systems, Shake table testing, Response history analysis

Posted Date: April 29th, 2021

DOl: https://doi.org/10.21203/rs.3.rs-460679/v1

License: (c) (i) This work is licensed under a Creative Commons Attribution 4.0 International License. Read Full License 


\section{Abstract}

Seismic isolation is generally considered an effective earthquake protection strategy. As application of seismic isolation increases, decisions on the use of one particular isolator versus another isolator increasingly depend on computed responses with complex analytical models. Accordingly, validation of analytical models to predict primary (structural) and secondary system (non-structural component) response in seismically isolated buildings becomes very important. This paper presents comparisons of experimental and analytical results on the primary and secondary system response of a building model in order to provide information on the accuracy of the predicted response. The tested model was configured as a 6-story building at quarter length scale in a moment-frame configuration, and with the following seismic isolation systems: a) Low damping elastomeric bearings with and without linear or nonlinear viscous dampers, b) Single Friction Pendulum (FP) bearings with and without linear or nonlinear viscous dampers, and c) Lead-rubber bearings. Response quantities compared include story drifts and isolator shear forces and displacements for the primary system, and peak floor total velocities and floor response spectra that relate to secondary system response. This paper presents samples results out of a total of 288 comparisons of experimental and analytical results presented in an MCEER report. It is shown that the primary and secondary system response is computed with sufficient accuracy by the analytical models but some response quantities may be underestimated or overestimated by significant amounts.

\section{Introduction}

Seismic isolation is a technology and construction strategy with a significant number of applications. Just in Japan, the number of applications exceeds 5000 large buildings and another 5000 one and twostory houses (Cilsalar et al. 2019). Worldwide applications of the technology include houses, apartment buildings, hospitals, museums, courthouses, emergency operation centers, LNG and other tanks, offshore oil and gas platforms, airport terminals, and high-rise buildings. The analysis and design of seismically isolated buildings is governed by codes and standards, and typically involves use of nonlinear response history analysis (e.g., Chap. 17 of standard ASCE 7-16; ASCE/SEI 2017). Results of the analysis used in design of seismically isolated buildings include the isolator resultant displacement, the base shear force, and story drift and shear forces. This paper compares analytical and experimental results on the isolator displacement, base shear force, and story drift that are used for the primary system design.

Codes and standards include specifications that are used for the design of secondary systems. Chapter 13 of ASCE 7-16 (ASCE/SEI 2017) presents equations for the design of non-structural components attached to floors. The equations include the peak floor acceleration that can be computed using prescriptive equations or response spectrum analysis procedures. For seismically isolated buildings, engineers often use these equations with the peak floor accelerations predicted by the nonlinear response history analysis procedures described in Chap. 17 of ASCE 7-16. Generally, the design of secondary systems is affected by many structural system response parameters, such as the structural drift (e.g., piping systems, cladding, etc.), the peak floor acceleration (e.g., rigidly attached equipment), the spectral floor acceleration (e.g., flexibly attached equipment), and combination of 
response parameters (e.g., cabinets and equipment that are allowed to rock, and complex systems such as sprinkler systems, gas supply systems, etc.). Accordingly, this paper also considers and compares analytical and experimental results on floor accelerations, floor total velocities and floor response spectra which are used or may be used for secondary system design.

Many past analytical studies (e.g., Kelly 1982; Chen and Soong 1988; Fan and Ahmadi 1990) and experimental studies (e.g., Kelly and Tsai 1985, 1988; Juhn et al. 1992; Soroushian et al. 2016; Ryan et al. 2016) considered the response of secondary systems attached to the primary system of seismically isolated buildings, where they established the potential benefits of seismic isolation in reducing the response of secondary systems. However, there has been little work on assessing the validity and accuracy of methods of analysis of seismically isolated buildings with emphasis on the secondary system response. Apart from a limited in scope study by Juhn et al. (1992), Wolff and Constantinou (2004) presented an extensive study on the verification of accuracy of methods of dynamic analysis of secondary systems in seismically isolated structures by comparing to experimental data. More recently, studies by Fenz and Constantinou (2008) and Sarlis et al. (2013) reported experimental results on isolated structures with double and triple friction pendulum isolators, including analytical predictions and comparison to experimental results on floor accelerations. Many more studies concentrated on validating analytical models of isolators by concentrating on the primary system response in terms, primarily, of isolators displacements and shear forces (e.g., Fenz and Constantinou 2008; Dao et al. 2013; Sarlis et al. 2013; Ryan et al. 2018).

In the study of Wolff and Constantinou (2004), on which this paper is based on, the tested model was $233 \mathrm{kN}$ in weight and configured as a 6-story building at quarter length scale in three building configurations (moment-frame, asymmetrically braced frame and symmetrically braced frame), and with the following seismic isolation systems: a) Low damping elastomeric bearings with and without linear or nonlinear viscous dampers, b) Single Friction Pendulum (FP) bearings with and without linear or nonlinear viscous dampers, c) Lead-rubber bearings, and d) Low damping elastomeric bearings in combination with flat sliding bearings. Response quantities compared included story drifts and shear forces, and isolator displacements for the primary system, and peak floor accelerations and velocities and floor response spectra that relate to secondary system response. A total of 227 experiments were conducted in 24 configurations ( 3 superstructures and 8 isolation systems) using 14 historic ground motions of far-fault and near-fault characteristics. This paper presents a sample of results from the Wolff and Constantinou (2004) study that concentrates on the structural system with the largest story drift and with contemporary configurations of isolation systems: the moment frame superstructure, elastomeric isolators with linear and nonlinear viscous dampers, friction pendulum isolators without and with linear and nonlinear viscous dampers and lead-rubber isolators. Also, results are presented for only two earthquake ground motions; the 1940 Imperial Valley, El Centro S00E record (peak acceleration of 0.34g, peak velocity of $0.34 \mathrm{~m} / \mathrm{sec}$-scaled up by factor of 2 for the test and with time compressed by factor of 2), a far-field motion, and the 1994 Northridge, Sylmar NR $90^{\circ}$ record (peak acceleration of $0.60 \mathrm{~g}$, peak velocity of $0.77 \mathrm{~m} / \mathrm{sec}$-used as recorded for the test and with time compressed by factor of 2), a near-fault 
motion. These two earthquake ground motions resulted in the largest isolator displacements which were, in the length scale of the tests, about $65 \mathrm{~mm}$ for the low damping elastomeric system and about $60 \mathrm{~mm}$ for the single FP system. Only one directional seismic excitation was used, which simplified the complexity of the analytical prediction. All analytical models were developed in program SAP2000 (Computer and Structures 2016), which nowadays is the most commonly used program in the analysis of seismically isolated buildings. The interested reader is referred to an extensive presentation of 288 comparisons of analytical and experimental results which is available in an MCEER report (Wolff and Constantinou 2004). Another paper of the authors (Wolff et al. 2015) presented another sample of results from this study concentrating on comparisons of the experimental responses, and some analytical predictions, of the model structure with elastomeric and single friction pendulum isolators when dampers were added to the isolation system.

\section{Description Of Test Structure And Experimental Program}

The test structure is shown in Fig. 1. The model represents a section in the weak direction of a steel moment-resisting frame. It is attached to a rigid base comprised of two AISC W14x90 sections, $5.2 \mathrm{~m}$ long with six transversely connected beams. The model has six stories of $0.915 \mathrm{~m}$ height each, giving a total height of $5.49 \mathrm{~m}$ above the base. The model is three bays by one bay in plan, each bay being $1.22 \mathrm{~m}$ wide, for total plan dimensions of $1.22 \mathrm{~m}$ by $3.66 \mathrm{~m}$. Concrete blocks were used to add mass to satisfy similitude requirements, bringing the total weight, including the base, to $233 \mathrm{kN}$. The structure was constructed with a length scale factor of 4 (prototype length to model length) and was tested with a time scale factor of 2 . The modal properties of the tested frame are discussed later when the analytical model is presented.

The seismic isolation system consisted of four isolators (either four elastomeric or four single friction pendulum or four lead-rubber isolators) and, when dampers were used, in combination with two linear or two nonlinear viscous dampers installed at angle of 40.4 degrees with respect the direction of testing (varied between 38 and 43degrees during testing due to change of length of the dampers). The elastomeric bearings were $177 \mathrm{~mm}$ in bonded diameter with a $25 \mathrm{~mm}$ mandrel hole. They consisted of 18 rubber layers of $3.2 \mathrm{~mm}$ thickness each for a total rubber thickness of $57 \mathrm{~mm}$. The rubber was natural rubber of grade 5 , hardness 50 and shear modulus of approximately $0.7 \mathrm{MPa}$. The lead-rubber bearings were identical in construction with the elastomeric bearings but with the mandrel hole fitted with a lead core. Accordingly, they referred to as low damping elastomeric bearings with lead core. The friction pendulum bearings had an actual radius (also effective radius due to the construction of the slider) of $762 \mathrm{~mm}$ and a displacement capacity of $200 \mathrm{~mm}$. The linear and the nonlinear dampers were designed so that they produce the same force at a velocity of approximately $350 \mathrm{~mm} / \mathrm{sec}$. Table 1 lists the properties of each element of the isolation system.

The properties were determined in testing of individual isolators and dampers under dynamic conditions and over three cycles. The elastomeric and lead-rubber bearings were tested at $1 \mathrm{~Hz}$ frequency, displacement amplitude corresponding to $100 \%$ rubber shear strain $(57 \mathrm{~mm})$ and various loads including 
the gravity load during shake table testing (the frequency of $1 \mathrm{~Hz}$ is related to the frequency of the model on the low damping elastomeric and lead-rubber isolation systems -1.1 to $1.25 \mathrm{~Hz}$ based on the postelastic stiffness in Table 1). The viscous dampers were tested at various velocities up to $350 \mathrm{~mm} / \mathrm{s}$ and displacement amplitude of $50 \mathrm{~mm}$. The friction pendulum bearings were tested at the gravity load, amplitude of $80 \mathrm{~mm}$ and peak velocities between 4.8 and $430 \mathrm{~mm} / \mathrm{s}$ (the range was needed to better calibrate the friction-velocity relationship). There was insignificant variation of the characteristic strength of the low damping elastomeric bearings and of the damper force, and there was some minor variation of the characteristic strength of the lead-rubber bearings and the friction force of the friction pendulum bearings from cycle to cycle in the tests. This result for the lead-rubber and friction pendulum bearings is inconsistent with the behavior of full-size bearings tested in prototype scale (Constantinou et al. 2007; Kalpakidis and Constantinou 2008, 2009) but consistent with the scaling principles used in the shake table testing (as demonstrated in Kalpakidis and Constantinou 2009, thermodynamic similarity requires to increase the velocity of motion when testing at reduced length scale, which is currently impossible to accomplish in shake table testing except at full scale). Accordingly, modeling the behavior of the isolators in the shake table testing had fewer complexities than modeling the behavior of full-size isolators.

Table 1

Properties of Individual Isolators and Dampers (average of three cycles)

\begin{tabular}{|c|c|c|c|}
\hline Element & $\begin{array}{l}\text { Elastic Stiffness } \\
(\mathrm{kN} / \mathrm{mm})\end{array}$ & $\begin{array}{l}\text { Post-elastic Stiffness } \\
\text { (kN/mm) }\end{array}$ & $\begin{array}{l}\text { Yield Force } \\
(\mathrm{kN})\end{array}$ \\
\hline $\begin{array}{l}\text { Low damping } \\
\text { elastomeric bearing }\end{array}$ & 0.55 & 0.30 & 3.1 \\
\hline \multirow[t]{2}{*}{ Lead-rubber bearing } & 5.25 & 0.37 & 10.7 \\
\hline & $\begin{array}{l}\text { Effective radius } \\
(\mathrm{mm})\end{array}$ & $\begin{array}{l}\text { Friction model } \\
\mathrm{f}_{\max } / f_{\min } / a\end{array}$ & $\begin{array}{l}\text { Initial } \\
\text { stiffness(kN/mm) }\end{array}$ \\
\hline \multirow{2}{*}{$\begin{array}{l}\text { Single friction pendulum } \\
\text { bearing }\end{array}$} & 762 & $0.08 / 0.02 / 20 \mathrm{sec} / \mathrm{m}$ & 175.0 \\
\hline & $\begin{array}{l}\text { Damping velocity } \\
\text { exponent q }\end{array}$ & $\begin{array}{l}\text { Damping constant } \\
\left(\mathrm{kN}-\sec ^{\mathrm{q}} / \mathrm{mm}^{\mathrm{q}}\right)\end{array}$ & $\begin{array}{l}\text { Angle of inclination } \\
\text { (degrees) }\end{array}$ \\
\hline Linear damper & 1 & 0.066 & 40.4 \\
\hline Nonlinear damper & 0.397 & 2.226 & 40.4 \\
\hline
\end{tabular}

The properties in Table 1 include the elastic and post-elastic stiffness and yield force for the elastomeric and lead-rubber bearings, damping constant $C$ and damping exponent $a$ for the dampers (Eq. 1), and effective radius of curvature, initial stiffness and friction coefficient model values for the friction pendulum isolators. The damper force $F$ is related to the damper relative velocity $V$ by:

$F=C V^{q} \operatorname{sgn}(V)$ 
The coefficient of friction follows the following relation (Constantinou et al. 1988), where $V$ is the velocity of sliding.

$$
\mu=f_{\max }-\left(f_{\max }-f_{\min }\right) \exp (-\alpha|V|)
$$

The properties of the isolation systems in terms of their characteristic strength over weight ratio $(Q / W)$ and period based on the post-elastic stiffness, in the time scale of the shake table tests, were:

1. Low damping elastomeric bearings: $Q / W=0.024$, period $=0.88 \mathrm{sec}$.

2. Low damping elastomeric with lead core (lead-rubber): $Q / W=0.17$, period $=0.80 \mathrm{sec}$.

3. Single friction pendulum: $Q / W=0.08$, period $=1.75 \mathrm{sec}$

The damping ratio of the combined low damping elastomeric bearing-linear damper system (using the bearing's post-elastic stiffness of $0.3 \mathrm{kN} / \mathrm{mm}$ ) is 0.23 .

The isolated model structure was tested with several historic earthquake motions using only one directional component. Results are presented in this paper for only two of these motions: (a) the 1940 Imperial Valley, El Centro record, component SOOE (peak acceleration of $0.34 \mathrm{~g}$, peak velocity of $0.34 \mathrm{~m} / \mathrm{sec}$-scaled up by factor of 2 for the test and with time compressed by factor of 2 ), a far-field motion, and (b) the 1994 Northridge, Sylmar record, component NR $90^{\circ}$ (peak acceleration of $0.60 \mathrm{~g}$, peak velocity of $0.77 \mathrm{~m} / \mathrm{sec}$-used as recorded for the test and with time compressed by factor of 2), a near-fault motion. These motions were selected for presentation in this paper as they resulted in the largest isolator displacements for the low damping elastomeric system (exceeding $100 \%$ rubber shear strain). The use of only one-directional excitation simplified the complexity of the analytical prediction of the response

\section{Analytical Model And Prediction On Response Of Tested Model}

Analytical prediction of the recorded response of the tested isolated model structure was performed using the commercial program SAP2000 (originally in version 7.44 and later verified in version 21; Computer and Structures, 2016). The interested reader is referred to Wolff and Constantinou (2004) for modeling and analysis using the public-domain program 3D-BASIS-ME (Tsopelas et al. 1994), which produced nearly identical results to those of program SAP2000. Results are presented in this paper and compared to experimental results for the following: (a) isolation system force-displacement loops, (b) histories of story drift at the story of maximum drift, (c) floor total velocities, and (d) floor acceleration spectra in the range of 0.1 to $20 \mathrm{~Hz}$.

The tested structure was modelled in SAP2000 using a skeletal representation with lumped masses at each joint as shown in Fig. 2. The model included rigid offsets to better represent the behavior of beams, columns and splices. Also, the loads cells below the isolators were modeled as they had some limited flexibility. Due to symmetry, only half of the tested structure was modelled having two instead of four isolators, and one damper instead of two. 
The modal characteristics of the tested model when fixed at it base were determined by processing of records acquired during shake table testing using banded $(0$ to $40 \mathrm{~Hz})$ white noise excitation of $0.05 \mathrm{~g}$ peak acceleration. Details of the identification are presented in Wolff and Constantinou (2004). These modal characteristics are presented in Table 2 and compared to those obtained by the analytical model. There is very agreement between the analytically and experimentally obtained frequencies and mode shapes. Based on the SAP2000 model, only the first three modes were necessary to achieve a $95 \%$ modal mass participation. The measured modal damping ratios were used in the global model of the isolated structure using a procedure that mirrored the one described in Sarlis et al. (2010).

Each isolator and each damper were explicitly modelled using the parameters in Table 1, which were determined experimentally. The same models were used in all analyses for all tests. There was no recalibration of the isolator and damper models based on the results obtained in the shake table testing. As an example, Fig. 3 shows a comparison of force-displacement loops for one of the lead-rubber bearings.

Figures 4 to 9 present comparisons of experimental analytical results for the FP system, without and with linear and nonlinear dampers. Figures 10 to 13 present comparisons of experimental analytical results for the low damping elastomeric system with linear and nonlinear dampers. Figures 14 and 15 present comparisons of experimental analytical results for the lead-rubber system. The compared results are (a) histories of the isolation system displacement and second story drift, (b) isolation system forcedisplacement loops, (c) 5\%-damped acceleration response spectra for the fifth floor and the base, and (d) histories of the base total velocity.

Table 2 Experimental and Analytical Modal Characteristics of Fixed Base Model

Experimental
\begin{tabular}{|c|c|c|c|c|c|c|c|c|}
\hline Mode & $\begin{array}{c}\text { Frequency } \\
(\mathrm{Hz})\end{array}$ & $\begin{array}{c}\text { Damping } \\
\text { Ratio }\end{array}$ & \multicolumn{7}{|c|}{ Mode Shape } \\
\cline { 4 - 9 } & & & \multicolumn{7}{|c|}{ Floor 1 } & Floor 2 & Floor 3 & Floor 4 & Floor 5 & Floor 6 \\
\hline \hline 1 & 2.34 & 0.048 & 0.22 & 0.43 & 0.60 & 0.77 & 0.94 & 1.00 \\
2 & 7.90 & 0.019 & -0.52 & -1.05 & -0.98 & -0.41 & 0.40 & 1.00 \\
3 & 13.65 & 0.011 & 0.98 & 1.02 & -0.27 & -1.27 & -0.59 & 1.00 \\
4 & 19.79 & 0.003 & -2.21 & 0.48 & 1.99 & -0.28 & -1.67 & 1.00 \\
5 & 25.45 & 0.014 & 2.51 & -1.66 & 0.14 & 2.40 & -2.86 & 1.00 \\
6 & 29.54 & 0.018 & -2.16 & 4.94 & -4.96 & 4.22 & -2.50 & 1.00 \\
\hline
\end{tabular}

Analytical

\begin{tabular}{|c|c|c|c|c|c|c|c|c|}
\hline \multirow{2}{*}{ Mode } & $\begin{array}{c}\text { Frequency } \\
(\mathrm{Hz})\end{array}$ & $\begin{array}{c}\text { Damping } \\
\text { Ratio }\end{array}$ & \multicolumn{7}{|c|}{ Mode Shape } \\
\cline { 4 - 9 } & & & \multicolumn{7}{|c|}{ Floor 1 } & Floor 2 & Floor 3 & Floor 4 & Floor 5 & Floor 6 \\
\hline & & & 0.19 & 0.43 & 0.64 & 0.80 & 0.93 & 1.00 \\
2 & 7.38 & & -0.57 & -0.98 & -0.87 & -0.36 & 0.42 & 1.00 \\
3 & 13.07 & \multirow{2}{*}{ NA } & 1.13 & 1.01 & -0.45 & -1.20 & -0.42 & 1.00 \\
4 & 19.60 & & -1.43 & 0.17 & 1.34 & -0.39 & -1.44 & 1.00 \\
5 & 25.58 & & 2.57 & -2.46 & 0.38 & 1.82 & -2.30 & 1.00 \\
6 & 32.25 & & -2.27 & 3.99 & -5.51 & 5.22 & -3.12 & 1.00 \\
\hline
\end{tabular}


The results in Figs. 4 to 15 (the interested reader is referred to Wolff and Constantinou, 2004 for many more comparisons) demonstrate good agreement between experimental and analytical results, although there are differences which are best depicted in the summary of results in Table 3. This table includes peak values of isolator displacement, second story drift ratio and base total velocity, and the fifth floor and base spectral acceleration values (5\%-damped spectra) at the frequency of $20 \mathrm{~Hz}$ (which is larger than but close to the peak floor acceleration). It may be seen in Figs. 4 to 15 and in Table 3 that, in general drift and floor total velocities are predicted very well by the analytical model. Also, the isolator displacement is predicted well but in one case in Table 3 the analytical model overpredicts the displacement by $35 \%$. This case of overprediction occurred for the low damping elastomeric system with nonlinear dampers. Wolff and Constantinou (2004) reported more similar cases of overprediction for the same system. Also, the analytical prediction often overpredicts or underpredicts the high frequency floor spectral acceleration values (which are close to the peak floor accelerations). The analytical model most often overpredicts accelerations (by as much as $50 \%$ ) for the friction pendulum and the lead-rubber isolation systems, and most often underpredicts the accelerations (by as much as $65 \%$ ) for the low damping elastomeric system with dampers. In most cases, the differences between analytical and experimental acceleration values are smaller, and typically not more than $25 \%$. Such differences are small but they need be viewed on the basis of the fact that the analytical models were based on extensive data on the building and isolation hardware, that the tested model lacked the complexity of a real building and that the seismic excitation was the simplest possible. For real buildings, in which knowledge of properties is incomplete and the seismic excitation is more complex, errors in the analytical prediction of response will likely much exceed $25 \%$. Accordingly, engineers should not make blind use of response history analysis results on peak values of accelerations and floor response spectra for assessing performance and for designing secondary systems. 
Table 3

Comparison of Experimental and Analytical Peak Response Quantities

\begin{tabular}{|c|c|c|c|c|c|}
\hline \multirow{2}{*}{$\begin{array}{l}\text { Isolation } \\
\text { System }\end{array}$} & \multirow{2}{*}{$\begin{array}{l}\text { Response } \\
\text { Quantity }\end{array}$} & \multicolumn{2}{|c|}{ El Centro 200\% } & \multicolumn{2}{|c|}{ Sylmar 100\% } \\
\hline & & Experiment & Analysis & Experiment & Analysis \\
\hline \multirow{5}{*}{$\begin{array}{l}\text { Friction } \\
\text { Pendulum }\end{array}$} & Isolator Displ. (mm) & 41 & 42 & 61 & 64 \\
\hline & 2nd Story Drift Ratio (\%) & 0.50 & 0.50 & 0.45 & 0.45 \\
\hline & 5th Floor Accel. at $20 \mathrm{~Hz}(\mathrm{~g})$ & 0.76 & 0.75 & 1.00 & 1.05 \\
\hline & Base Accel. at $20 \mathrm{~Hz}(\mathrm{~g})$ & 0.76 & 0.76 & 0.88 & 1.10 \\
\hline & Base Velocity (mm/sec) & 232 & 232 & 288 & 288 \\
\hline \multirow{5}{*}{$\begin{array}{l}\text { Friction } \\
\text { Pendulum } \\
\text { With Linear } \\
\text { Dampers }\end{array}$} & Isolator Displ. (mm) & 29 & 29 & 41 & 41 \\
\hline & 2nd Story Drift Ratio (\%) & 0.50 & 0.50 & 0.55 & 0.55 \\
\hline & 5th Floor Accel. at $20 \mathrm{~Hz}(\mathrm{~g})$ & 0.86 & 0.81 & 1.00 & 0.92 \\
\hline & Base Accel. at $20 \mathrm{~Hz}(\mathrm{~g})$ & 0.81 & 0.81 & 0.78 & 0.78 \\
\hline & Base Velocity (mm/sec) & 242 & 242 & 284 & 284 \\
\hline \multirow{5}{*}{$\begin{array}{l}\text { Friction } \\
\text { Pendulum } \\
\text { With Nonlinear } \\
\text { Dampers }\end{array}$} & Isolator Displ. (mm) & 23 & 23 & 37 & 40 \\
\hline & 2nd Story Drift Ratio (\%) & 0.62 & 0.62 & 0.60 & 0.60 \\
\hline & 5th Floor Accel. at $20 \mathrm{~Hz}(\mathrm{~g})$ & 1.05 & 1.05 & 1.11 & 1.05 \\
\hline & Base Accel. at $20 \mathrm{~Hz}(\mathrm{~g})$ & 0.97 & 1.30 & 0.85 & 1.15 \\
\hline & Base Velocity (mm/sec) & 224 & 272 & 280 & 280 \\
\hline \multirow{5}{*}{$\begin{array}{l}\text { Low Damping } \\
\text { Elastomeric } \\
\text { With Linear } \\
\text { Dampers }\end{array}$} & Isolator Displ. (mm) & 39 & 38 & 42 & 46 \\
\hline & 2nd Story Drift Ratio (\%) & 0.45 & 0.49 & 0.53 & 0.48 \\
\hline & 5th Floor Accel. at $20 \mathrm{~Hz}(\mathrm{~g})$ & 0.59 & 0.38 & 0.65 & 0.44 \\
\hline & Base Accel. at $20 \mathrm{~Hz}(\mathrm{~g})$ & 0.65 & 0.46 & 0.59 & 0.46 \\
\hline & Base Velocity (mm/sec) & 300 & 336 & 350 & 350 \\
\hline \multirow{3}{*}{$\begin{array}{l}\text { Low Damping } \\
\text { Elastomeric } \\
\text { With }\end{array}$} & Isolator Displ. (mm) & 25 & 29 & 32 & 43 \\
\hline & 2nd Story Drift Ratio (\%) & 0.56 & 0.56 & 0.61 & 0.61 \\
\hline & 5th Floor Accel. at $20 \mathrm{~Hz}(\mathrm{~g})$ & 0.86 & 0.76 & 1.05 & 0.66 \\
\hline \multirow{2}{*}{$\begin{array}{l}\text { Nonlinear } \\
\text { Dampers }\end{array}$} & Base Accel. at $20 \mathrm{~Hz}(\mathrm{~g})$ & 0.84 & 0.68 & 0.81 & 0.65 \\
\hline & Base Velocity (mm/sec) & 305 & 305 & 313 & 350 \\
\hline Lead-rubber & Isolator Displ. (mm) & 28 & 26 & 38 & 35 \\
\hline
\end{tabular}




\begin{tabular}{lllll|} 
2nd Story Drift Ratio (\%) & 0.55 & 0.55 & 0.62 & 0.59 \\
\hline 5th Floor Accel. at 20Hz (g) & 0.66 & 1.00 & 0.73 & 0.61 \\
\hline Base Accel. at 20Hz (g) & 0.73 & 0.89 & 0.73 & 0.66 \\
\hline Base Velocity (mm/sec) & 340 & 340 & 400 & 400 \\
\hline
\end{tabular}

\section{Summary And Conclusions}

This paper presented a comparison of a sample of experimental and analytical results on the response of seven different seismic isolation systems in two different strong ground motions. A significant larger collections of similar comparisons may be found in an MCEER report of the authors. The presented results are for a model of $233 \mathrm{kN}$ in weight, configured as a 6-story moment frame building at quarter length scale, and with the following seismic isolation systems: a) Low damping elastomeric bearings with and without linear or nonlinear viscous dampers, b) Single Friction Pendulum (FP) bearings with and without linear or nonlinear viscous dampers, and c) Lead-rubber bearings. Response quantities compared in this paper include story drifts, and isolator shear forces and displacements for the primary system, and floor total velocities and floor acceleration response spectra that relate to secondary system response.

In general, the isolator displacements, the story drift and the floor total velocities are predicted very well by the analytical model. However, the analytical model overpredicted the isolator displacements in the low damping elastomeric system with nonlinear dampers (also, see Wolff and Constantinou, 2004 for more similar results for this system). Moreover, the analytical prediction often overpredicted or underpredicted the high frequency floor spectral acceleration values (which are close to the peak floor accelerations). The analytical model most often overpredicted accelerations for the friction pendulum and the lead-rubber isolation systems, and most often underpredicted the accelerations for the low damping elastomeric system with dampers. In most cases, the differences between analytical and experimental acceleration values were about $25 \%$. Such differences are small but they need be viewed on the basis of the fact that the analytical models were based on extensive experimental data on the building and isolation hardware, that the tested model lacked the complexity of a real building and that the seismic excitation was the simplest possible. For real buildings, in which knowledge of properties is incomplete and the seismic excitation is more complex, errors in the analytical prediction of response will likely much exceed $25 \%$. Accordingly, engineers should not make blind use of response history analysis results on peak values of accelerations and floor response spectra for assessing performance and for designing secondary systems.

\section{Declarations}

\section{ACKNOWLEDGEMENTS}

Partial support for the work presented in this paper has been provided by the Multidisciplinary Center for Earthquake Engineering Research, University at Buffalo, Buffalo, NY. The Friction Pendulum isolators 
were manufactured by Earthquake Protection Systems of Vallejo, California. The viscous dampers were manufactured by Taylor Devices of North Tonawanda, NY. The elastomeric bearings were manufactured by Dynamic Isolation Systems of Sparks, Nevada.

\section{References}

1. ASCE/SEI 7-16 (2017) Minimum design loads and associated criteria for buildings and other structures. American Society of Civil Engineers, VA, USA

2. Chen Y, Soong TT (1988) Seismic Response of Secondary Systems. Eng Struct 10(4):218-228. https://doi.org/10.1016/0141-0296(88)90043-0

3. Cilsalar H, Constantinou MC (2019) Behavior of a spherical deformable rolling seismic isolator for lightweight residential construction. Bull of Earthq Eng 18(4):1475-1498. https://doi.org/10.1007/s10518-019-00626-z

4. Computers, Structures I (2016) SAP2000, Integrated Finite Element Analysis and Design of Structures. Version 21, Berkeley, California

5. Constantinou MC, Mokha A, Reinhorn A (1990) Teflon bearings in base isolation. II: modeling. J Struct Eng ASCE 116(2):455-474. https:// doi.org/10.1061/(ASCE)0733-9445(1990)116:2(455)

6. Constantinou MC, Whittaker AS, Kalpakidis Y, Fenz DM, Warn GP (2007) Performance of seismic isolation hardware under service and seismic loading Report No. MCEER-07-0012. Multidisciplinary Center for Earthquake Engineering Research, Buffalo

7. Dao ND, Ryan KL, Sato E, Sasaki T (2013) Predicting the displacement of triple pendulum bearings in a full-scale shaking experiment using a three-dimensional element. Earthq Eng Struct Dyn 42(11):1677-1695. https://doi.org/10.1002/eqe.2293

8. Fan FG, Ahmadi G (1990) Floor Response Spectra for Base-Isolated Multistory Structures Earthq Eng Struct Dyn 19 (3):377-388. https://doi.org/10.1002/eqe.4290190307

9. Fenz DM, Constantinou MC (2008) Mechanical behavior of multi-spherical sliding bearings Report No. MCEER-08-0007. Multidisciplinary Center for Earthquake Engineering Research, Buffalo

10. Juhn G, Manolis GD, Constantinou MC, Reinhorn AM (1992) Experimental Study of Secondary Systems in Base-Isolated Structures J Struct Eng, ASCE 118 (8). https://doi.org/10.1061/(ASCE)0733-9445(1992)118:8(2204)

11. Kalpakidis IV, Constantinou MC (2009) Effects of heating on the behavior of lead-rubber bearings. I: theory. J Struct Eng ASCE 135(12):1440-1449. https://doi.org/10.1061/(ASCE)ST.1943$541 \times .0000071$

12. Kalpakidis IV, Constantinou MC (2010) Principles of scaling and similarity for testing of lead-rubber bearings. Earthq Eng Struct Dyn 39(13):1551-1568. https://doi.org/10.1002/eqe.1041

13. Kelly JM (1982) The Influence of Base Isolation on The Seismic Response of Light Secondary Equipment UCB/EERC-81/17, Berkeley, CA 
14. Kelly JM, Tsai HC (1985) Seismic Response of Light Internal Equipment in Base-Isolated. Structures Earthq Eng Struct Dyn 13(6):711-732. https://doi.org/10.1002/eqe.4290130603

15. Kelly JM, Tsai HC (1988) Seismic Response of The Superstructure and Attached Equipment in a Base Isolated Building. Earthq Eng Struct Dyn 18(4):551-564. https://doi.org/10.1002/eqe.4290180409

16. Ryan KL, Soroushian S, Maragakis EM, Sato E, Sasaki T, Okazaki T (2016) Seismic Simulation of an Integrated Ceiling-Partition Wall-Piping System at E-Defense. I: Three-Dimensional Structural Response and Base Isolation. J Struct Eng ASCE 142(2):04015130. https://doi.org/10.1061/(ASCE)ST.1943-541X.0001384

17. Ryan KL, Okazaki T, Coria CB, Sato E, Sasaki T (2018) Response of hybrid isolation system during a shake table experiment of a full-scale isolated building. Earthq Eng Structl Dyn 47(11):2214-2232. https://doi.org/10.1002/eqe.3065

18. Sarlis AA, Constantinou MC (2010) Modeling triple friction pendulum isolators in program SAP2000, document distributed to the engineering community together with example files, University at Buffalo

19. Sarlis AA, Constantinou MC, Reinhorn AM (2013) Shake table testing of triple frictıon pendulum isolators under extreme conditions Technical Report No. MCEER-13-0011, Multidisciplinary Center for Earthquake Engineering Research, State University of New York at Buffalo, Buffalo, NY

20. Soroushian S, Maragakis EM, Ryan KL, Sato E, Sasaki T, Okazaki T, Mosqueda G (2016) Seismic simulation of integrated ceiling-partition wall-piping system at E-Defense. II: Evaluation of nonstructural damage and fragilities. J Struct Eng ASCE 142(2):04015131

21. https://doi.org/10.1061/(ASCE)ST.1943-541X.0001385, 04015131

22. Tsopelas PC, Constantinou MC, Reinhorn AM (1994) 3D-BASIS-ME: Computer Program for Nonlinear Dynamic Analysis of Seismically Isolated Single and Multiple Structures and Liquid Storage Tanks Report No. MCEER-94-0010, Multidisciplinary Center for Earthquake Engineering Research. State University of New York, Buffalo

23. Wolff ED, Constantinou MC (2004) Experimental study of seismic isolation systems with emphasis on secondary system response and verification of accuracy of dynamic response history analysis methods. In: Report No. MCEER-04-0001. Multidisciplinary Center for Earthquake Engineering Research, Buffalo

24. Wolff ED, Ipek C, Constantinou MC, Tapan M (2015) Effect of Viscous Damping Devices on the Response of Seismically Isolated Structures Earthq Eng Struct Dyn 44 (2):185-198. https://doi.org/10.1002/eqe.2464

\section{Figures}




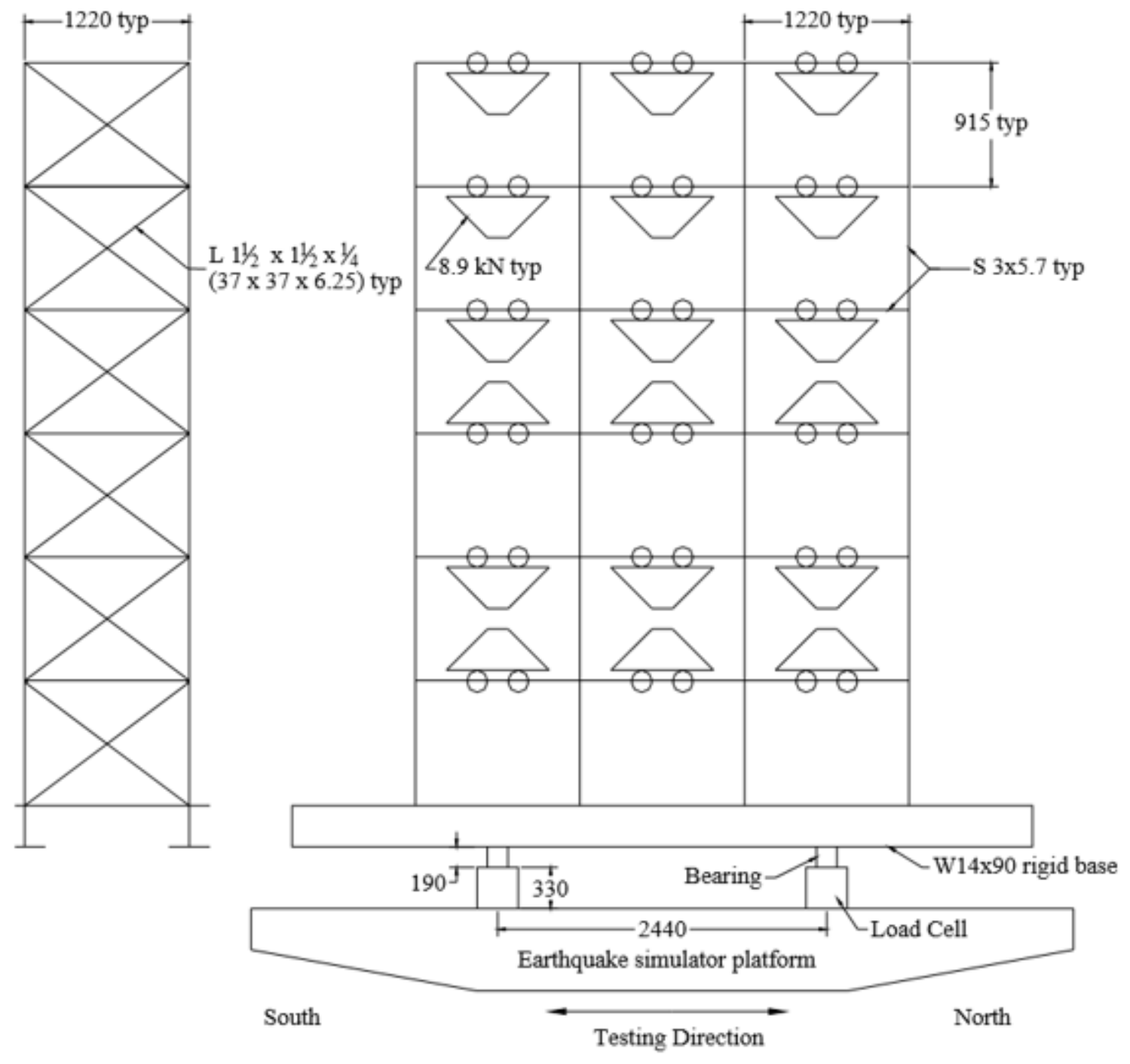

(all units in $\mathrm{mm}$ )

\section{Figure 1}

Schematic of Tested Six-Story Isolated Model Building 


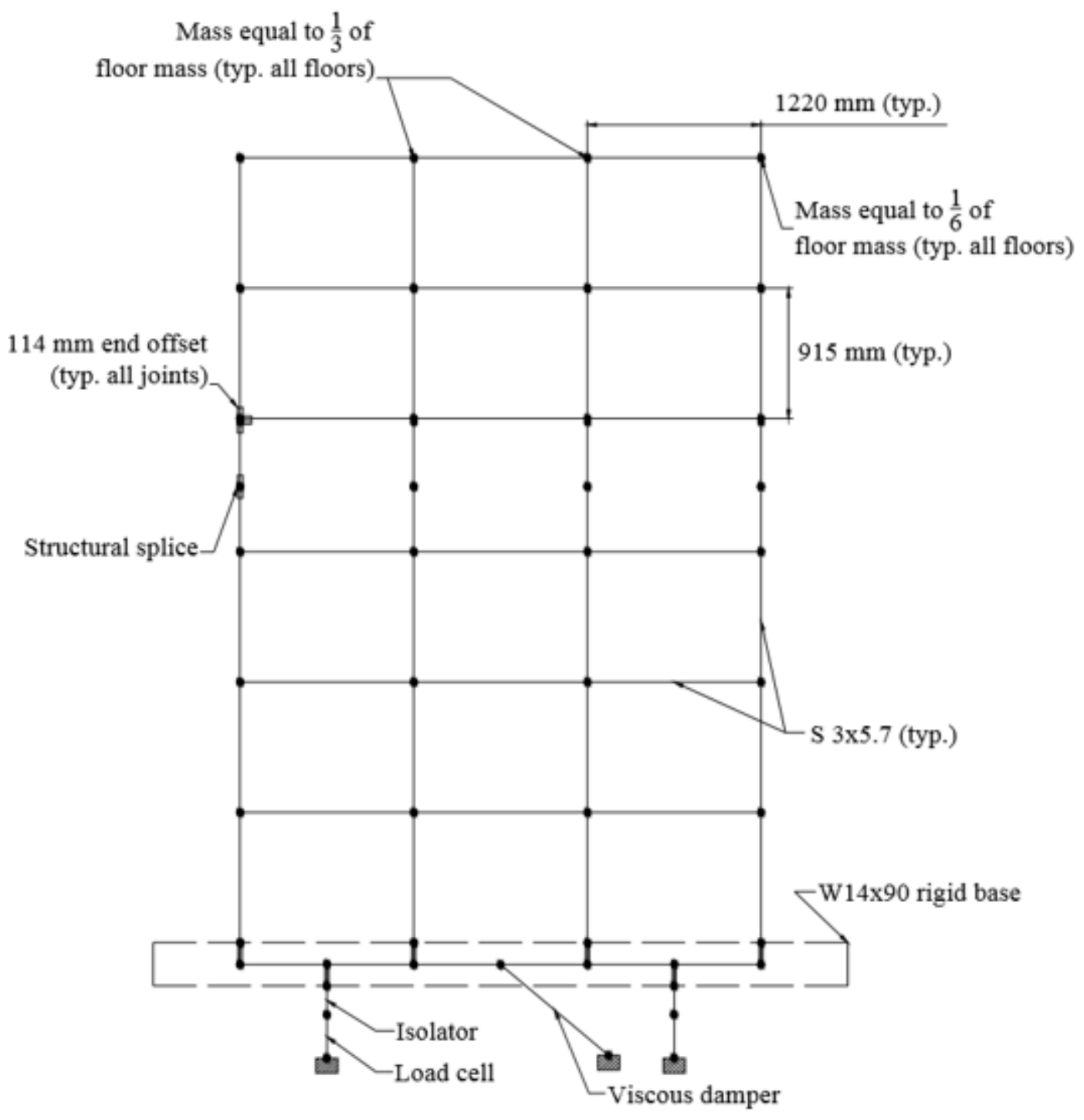

Figure 2

Model of Six-Story Isolated Structure in Program SAP2000 

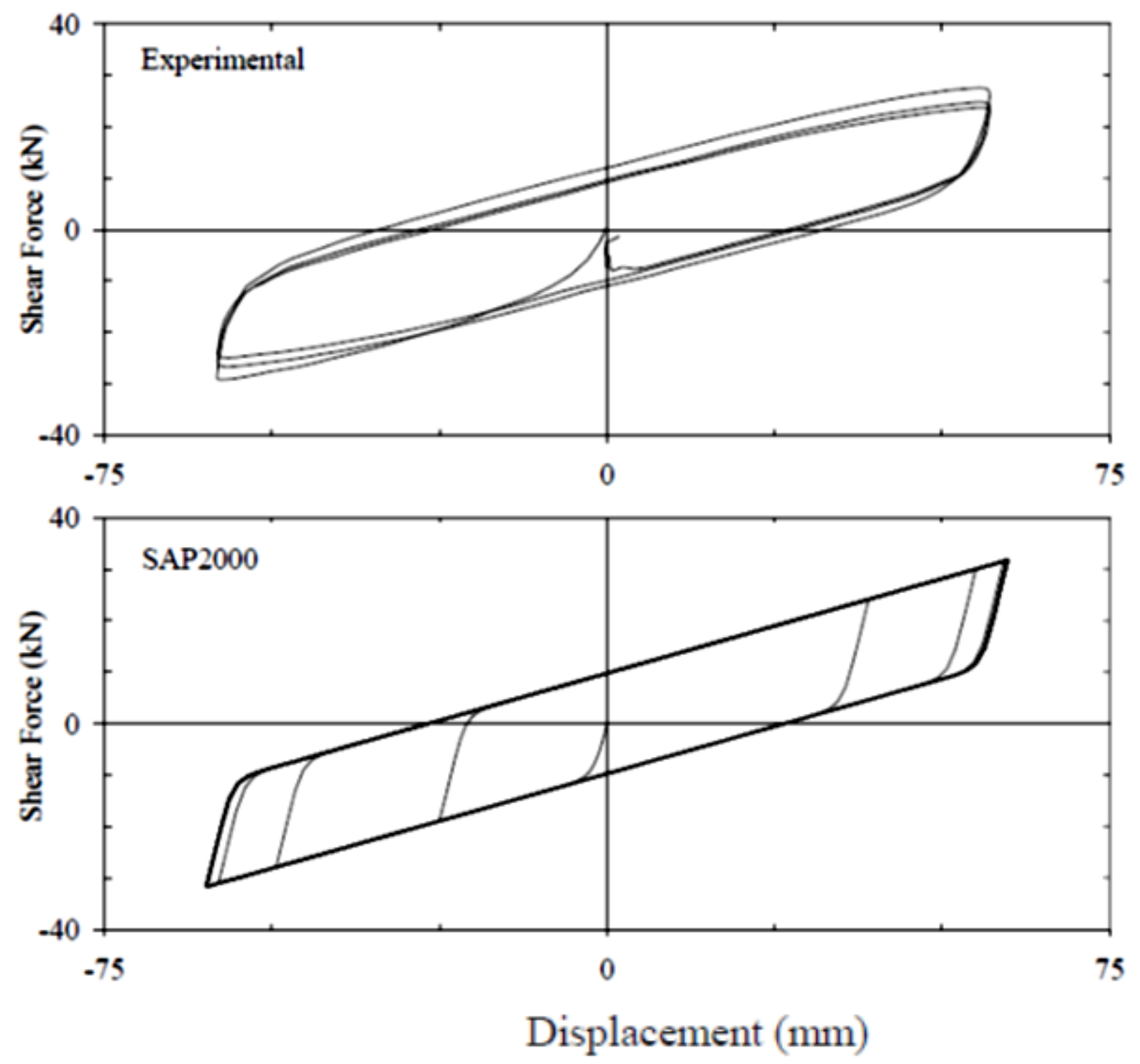

Figure 3

Experimental and Analytical Lead-rubber Bearing Force-displacement Loops (Test with load $=62.3 \mathrm{kN}$, frequency $=1 \mathrm{~Hz}$, amplitude $=57 \mathrm{~mm}$ ) 


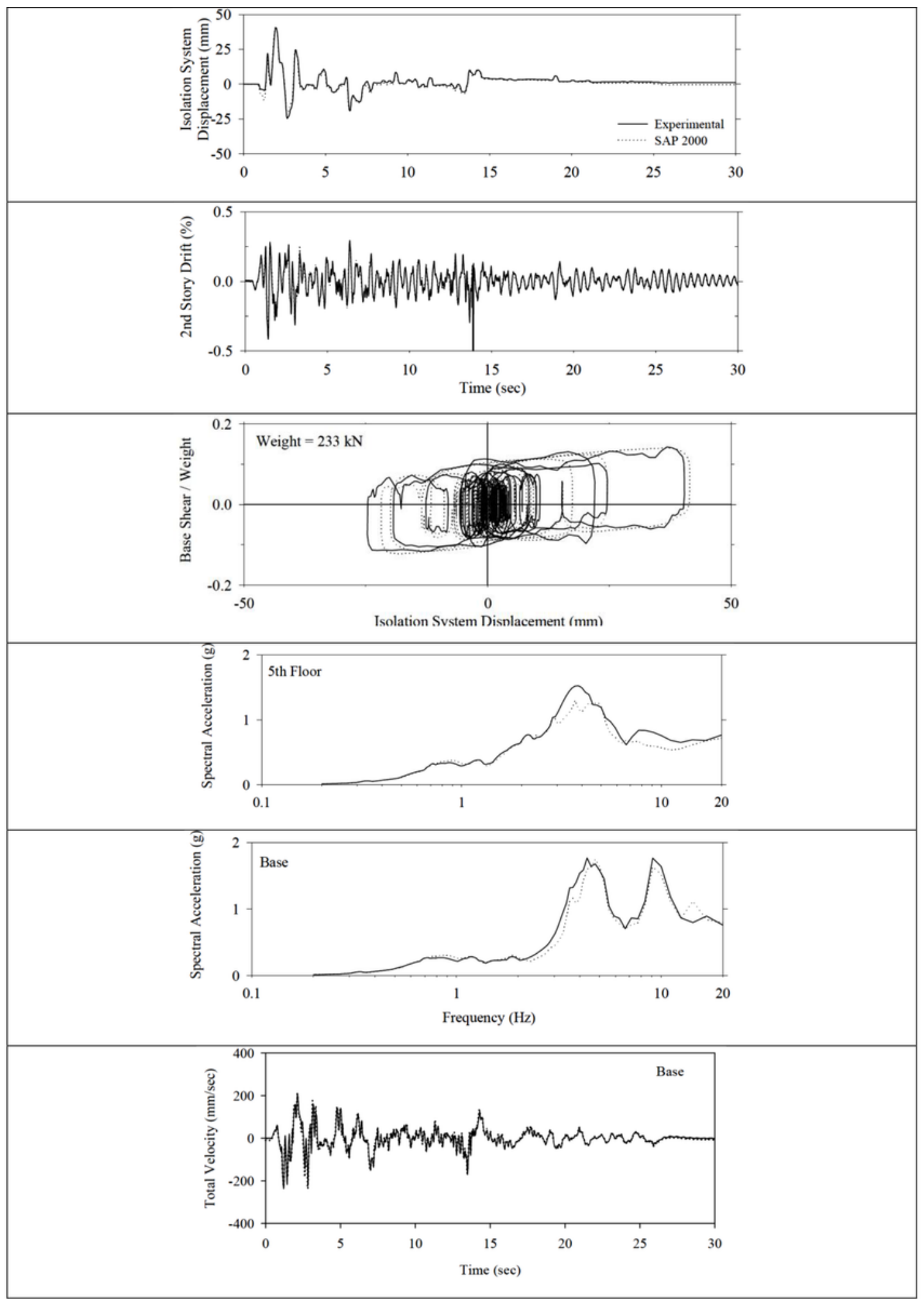

\section{Figure 4}

Comparison of Results for FP System in El Centro 200\% 


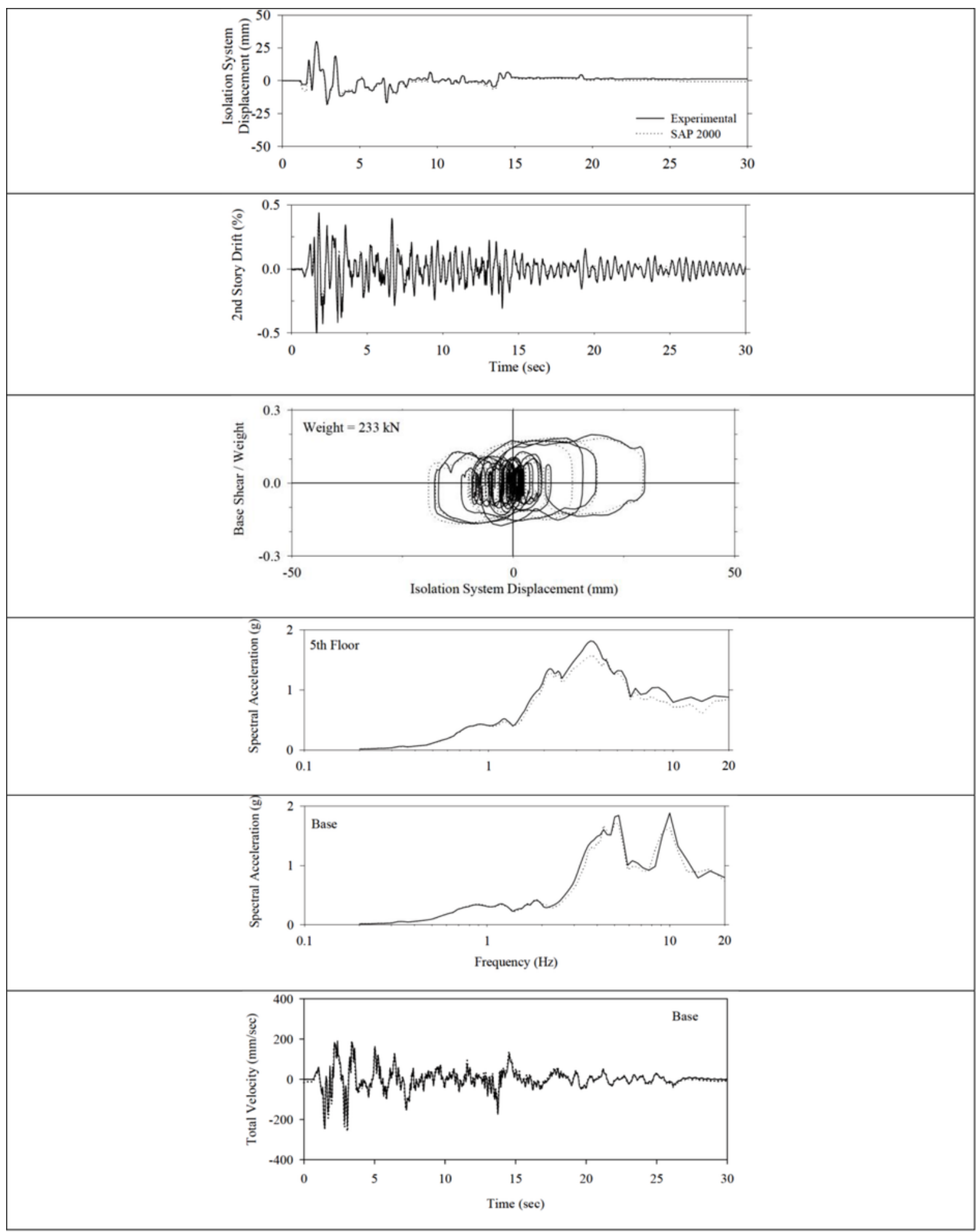

\section{Figure 5}

Comparison of Results for FP System with Linear Dampers in El Centro 200\% 


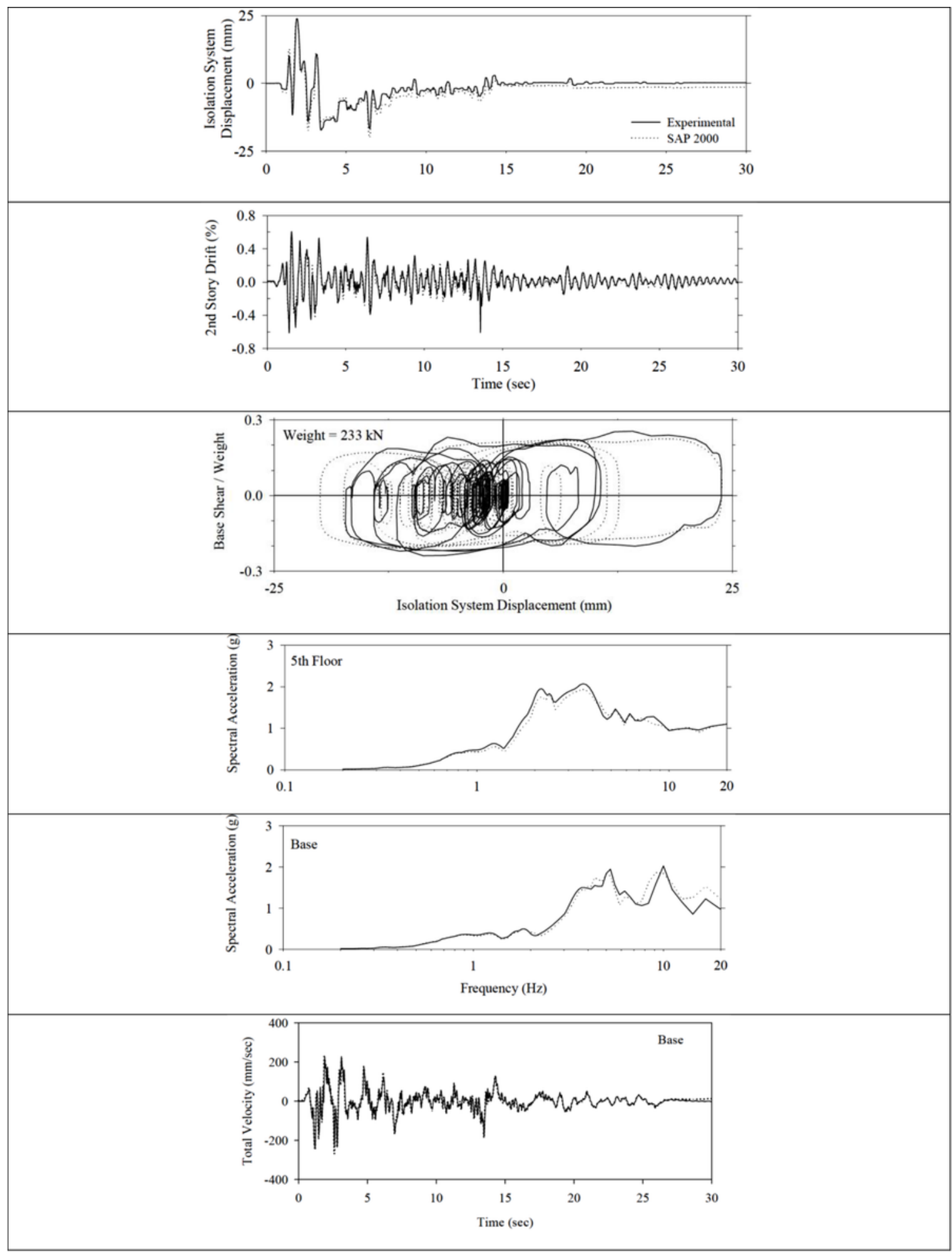

\section{Figure 6}

Comparison of Results for FP System with Nonlinear Dampers in El Centro 200\% 


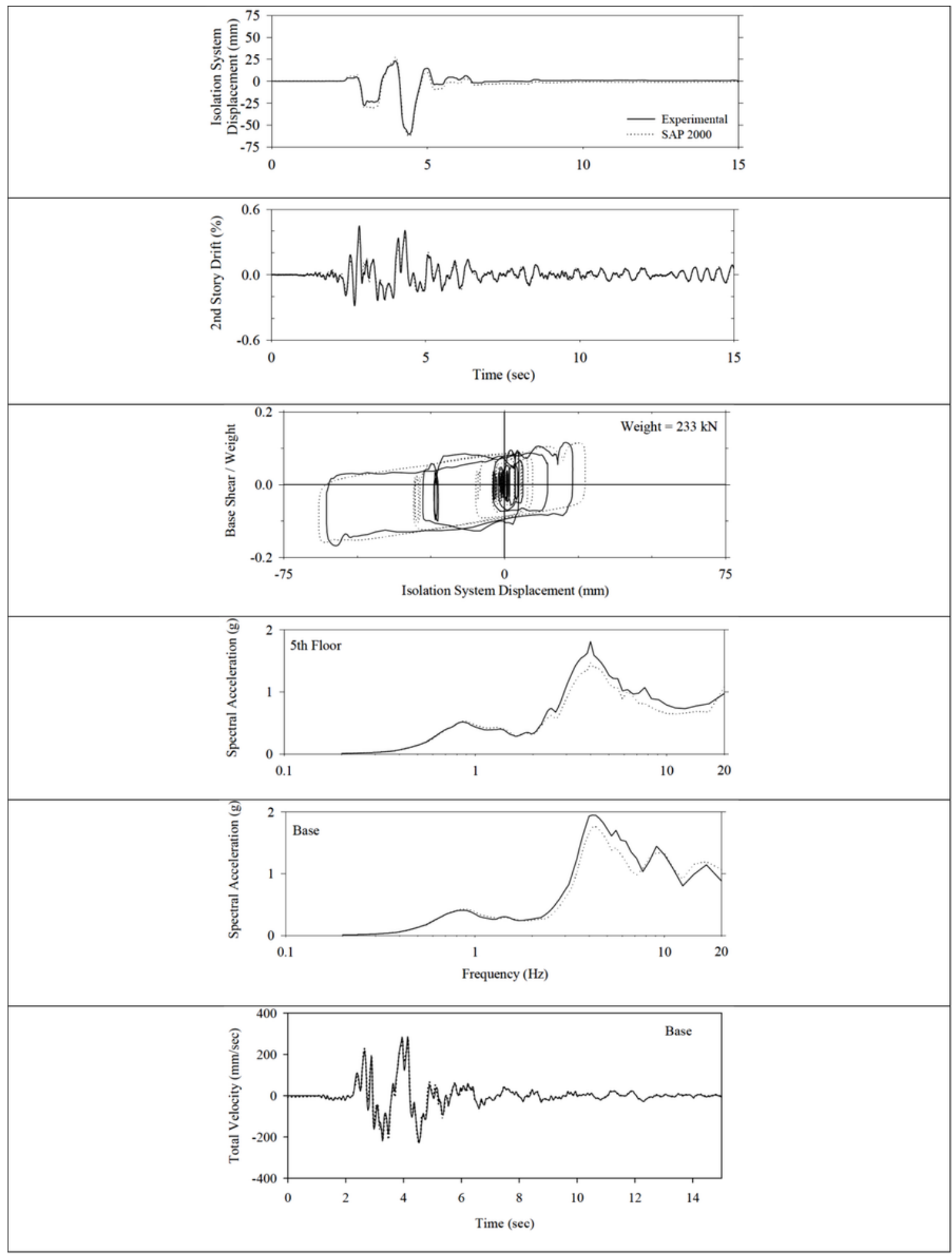

\section{Figure 7}

Comparison of Results for FP System in Sylmar 100\% 


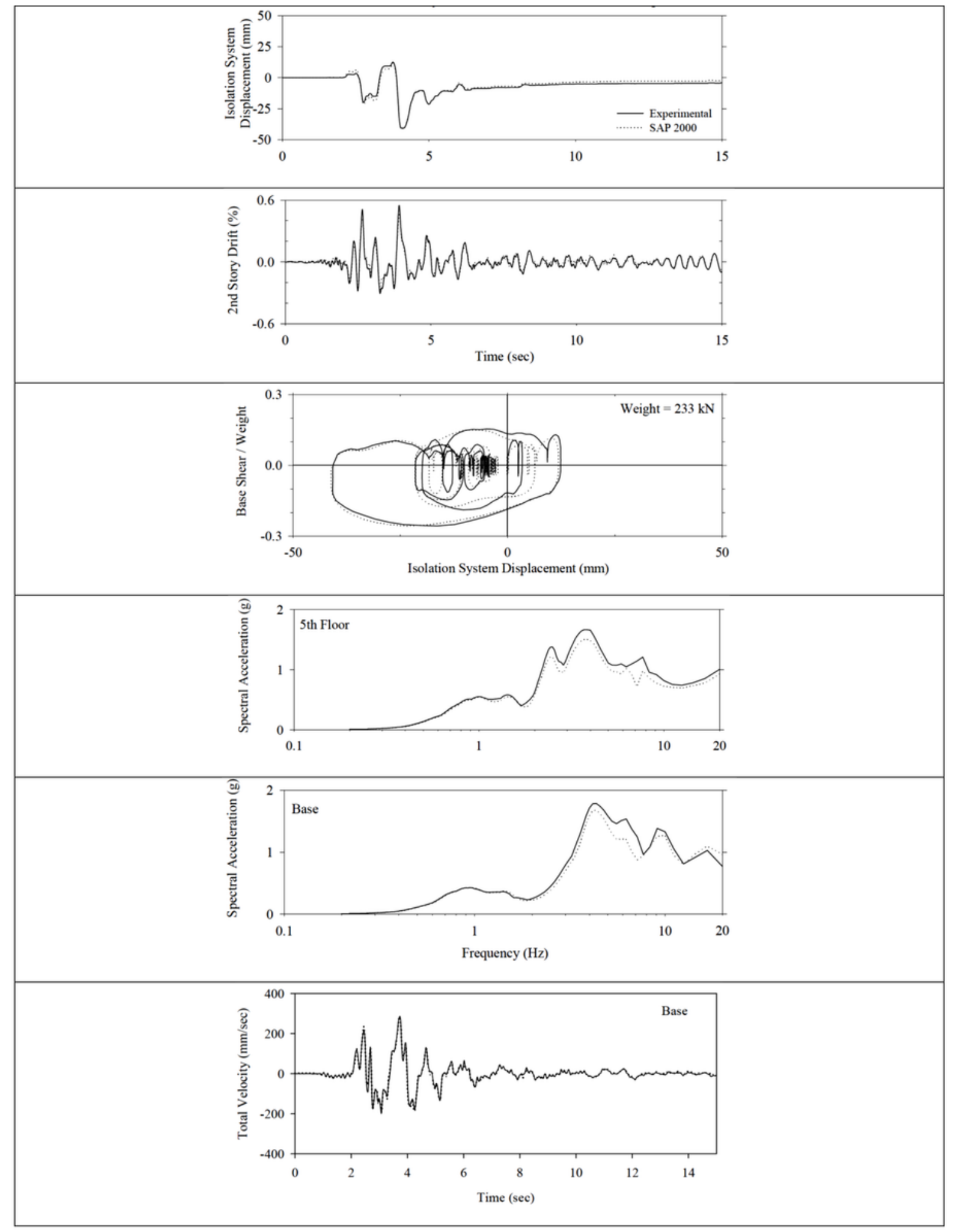

\section{Figure 8}

Comparison of Results for FP System with Linear Dampers in Sylmar 100\% 


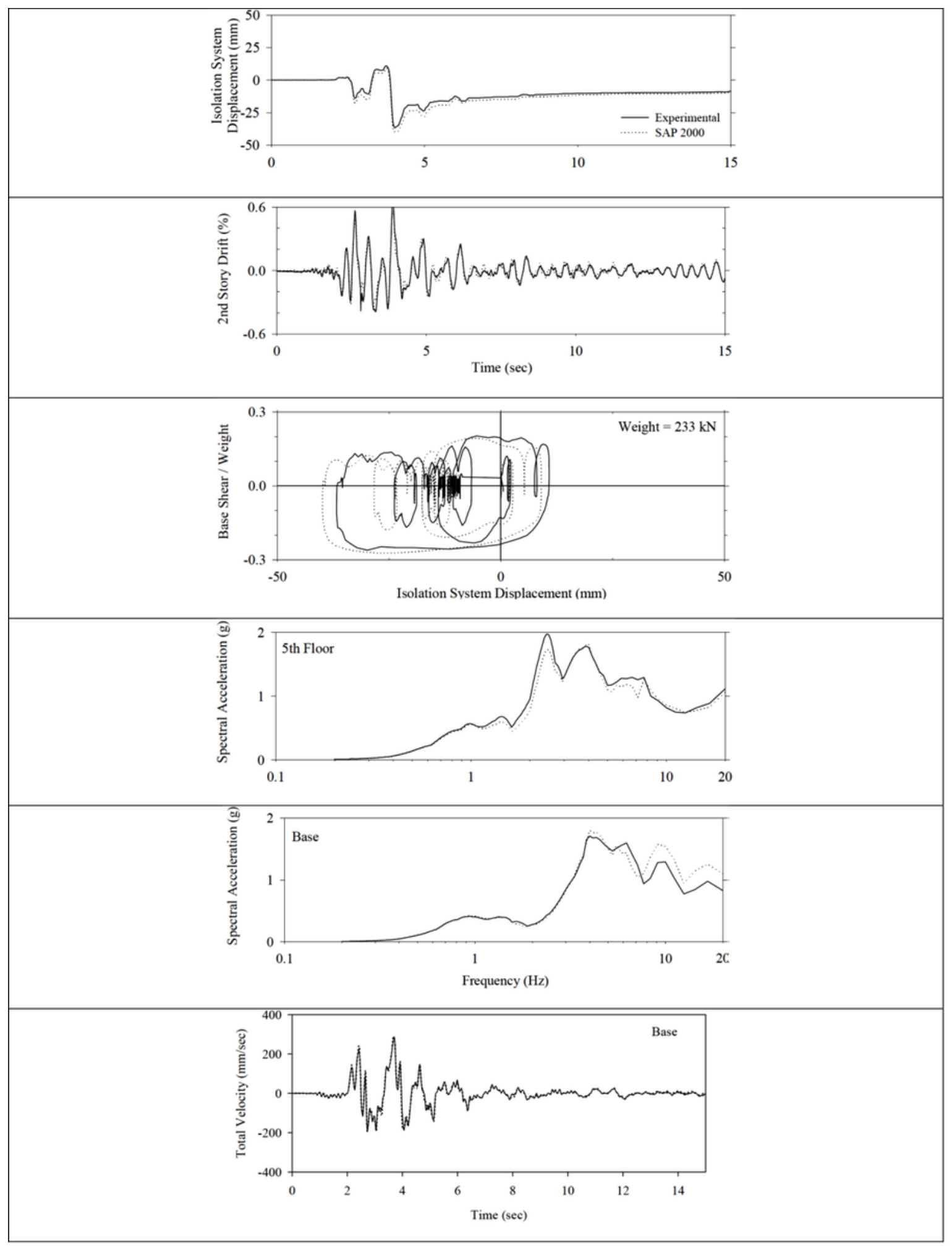

\section{Figure 9}

Comparison of Results for FP System with Nonlinear Dampers in Sylmar 100\% 


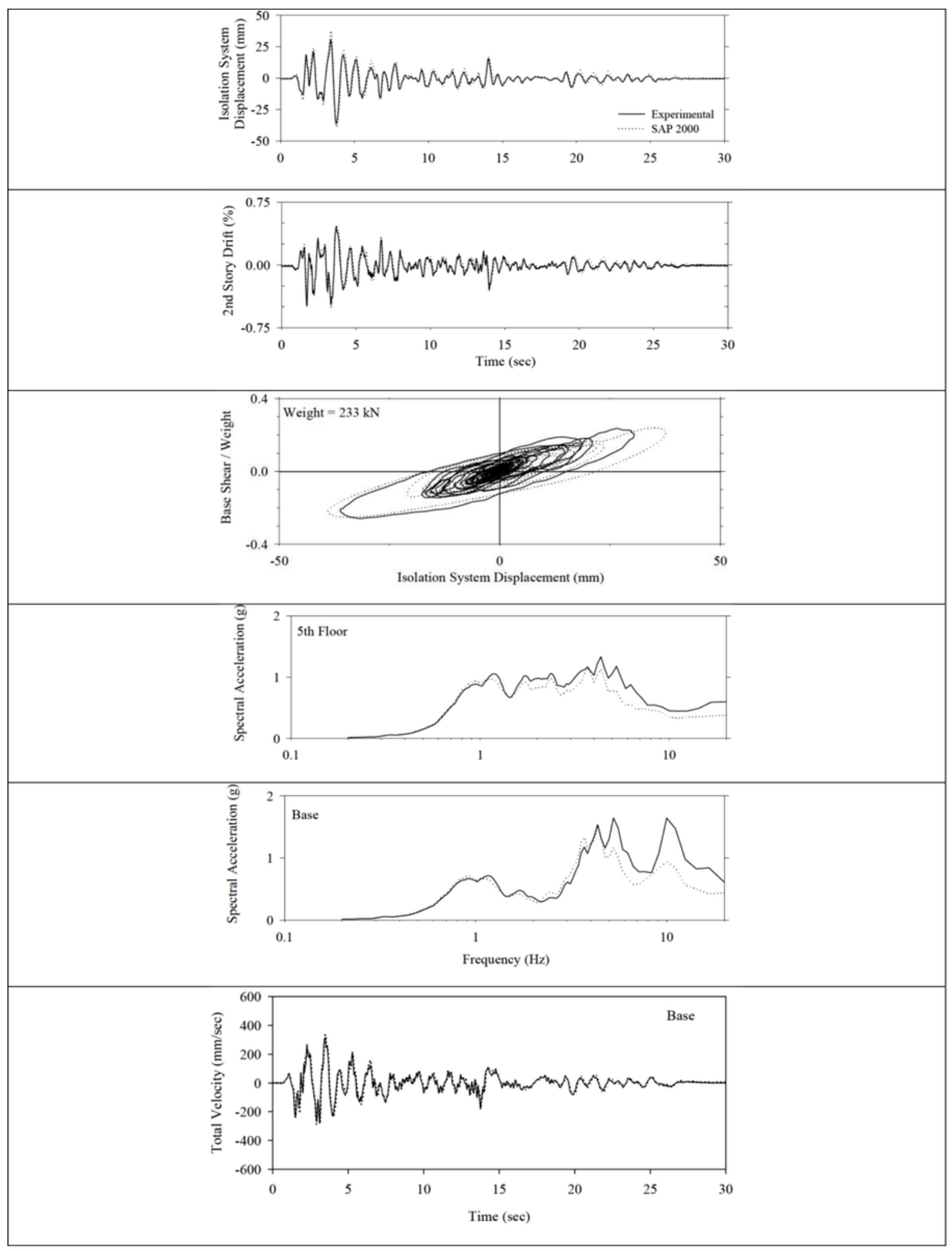

\section{Figure 10}

Comparison of Results for Elastomeric System with Linear Dampers in El Centro 200\% 


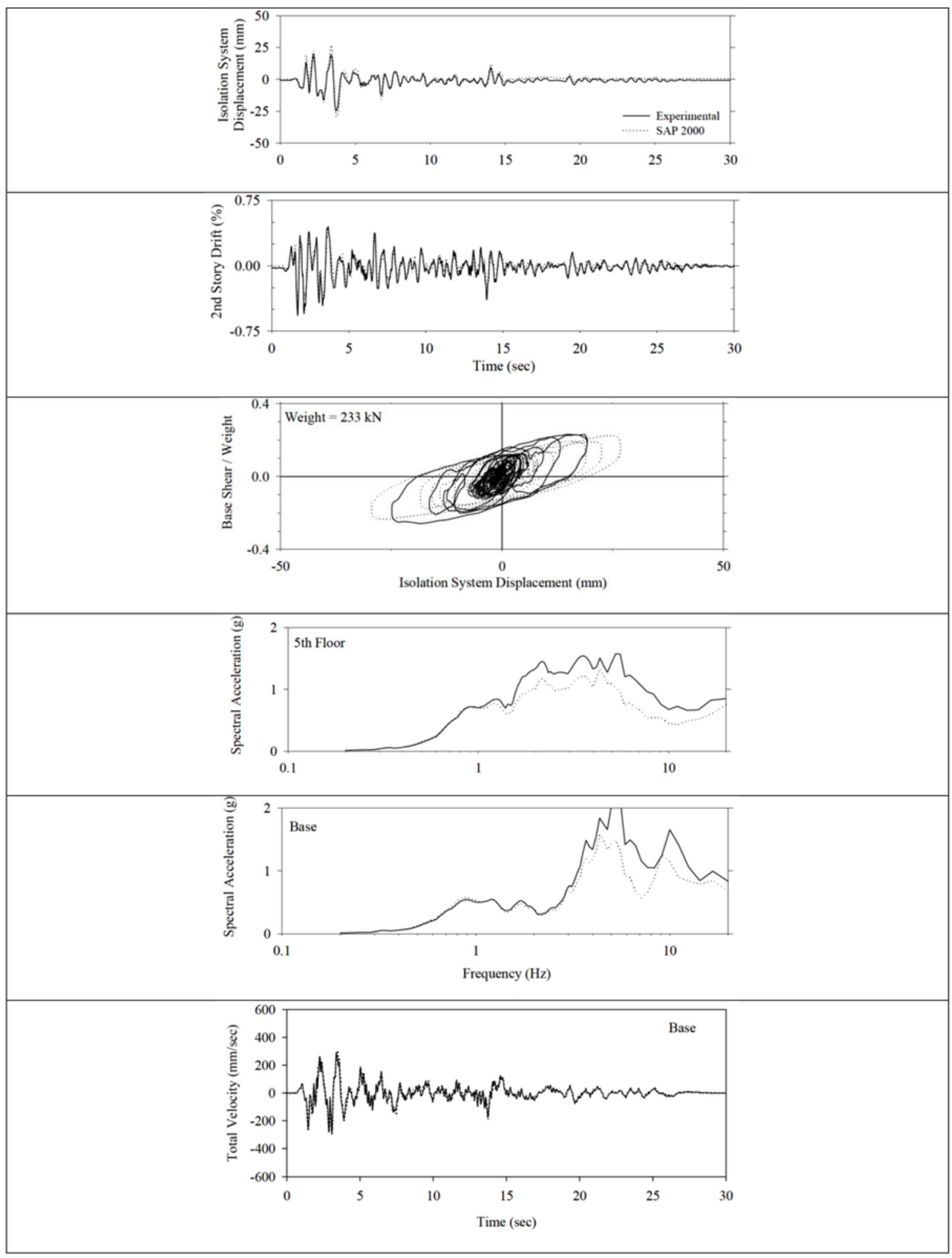

\section{Figure 11}

Comparison of Results for Elastomeric System with Nonlinear Dampers in El Centro 200\% 


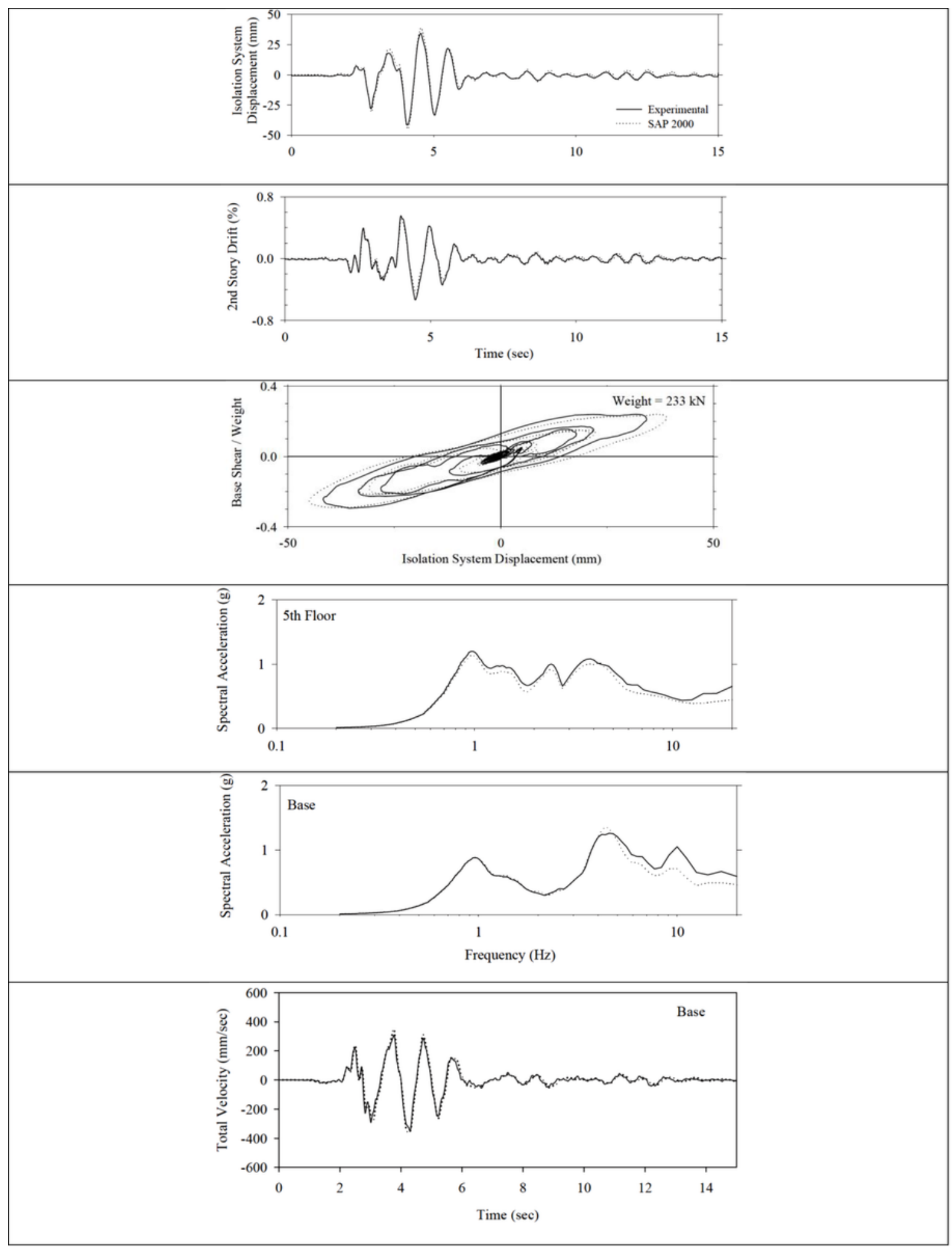

Figure 12

Comparison of Results for Elastomeric System with Linear Dampers in Sylmar 100\% 


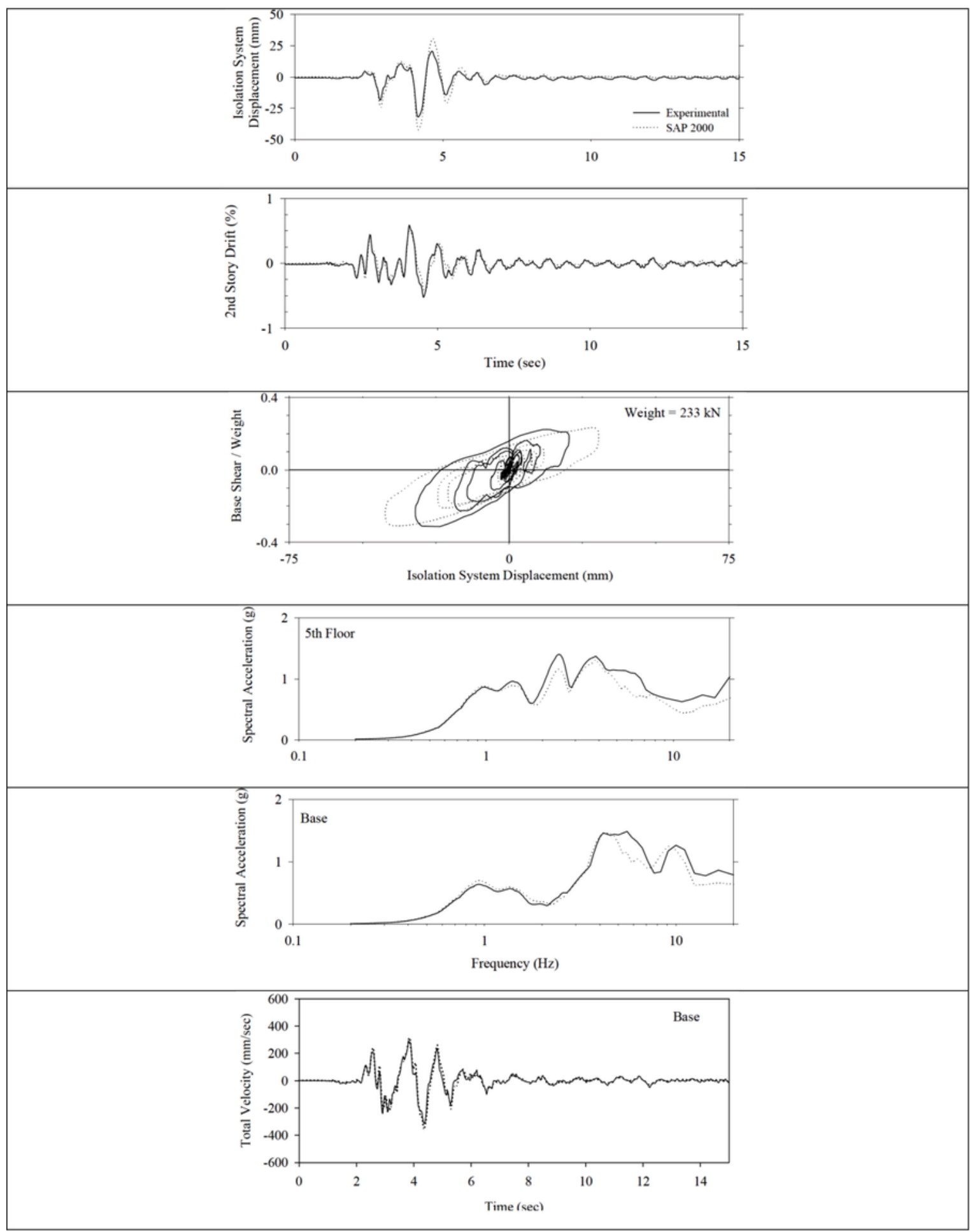

\section{Figure 13}

Comparison of Results for Elastomeric System with Nonlinear Dampers in Sylmar 100\% 


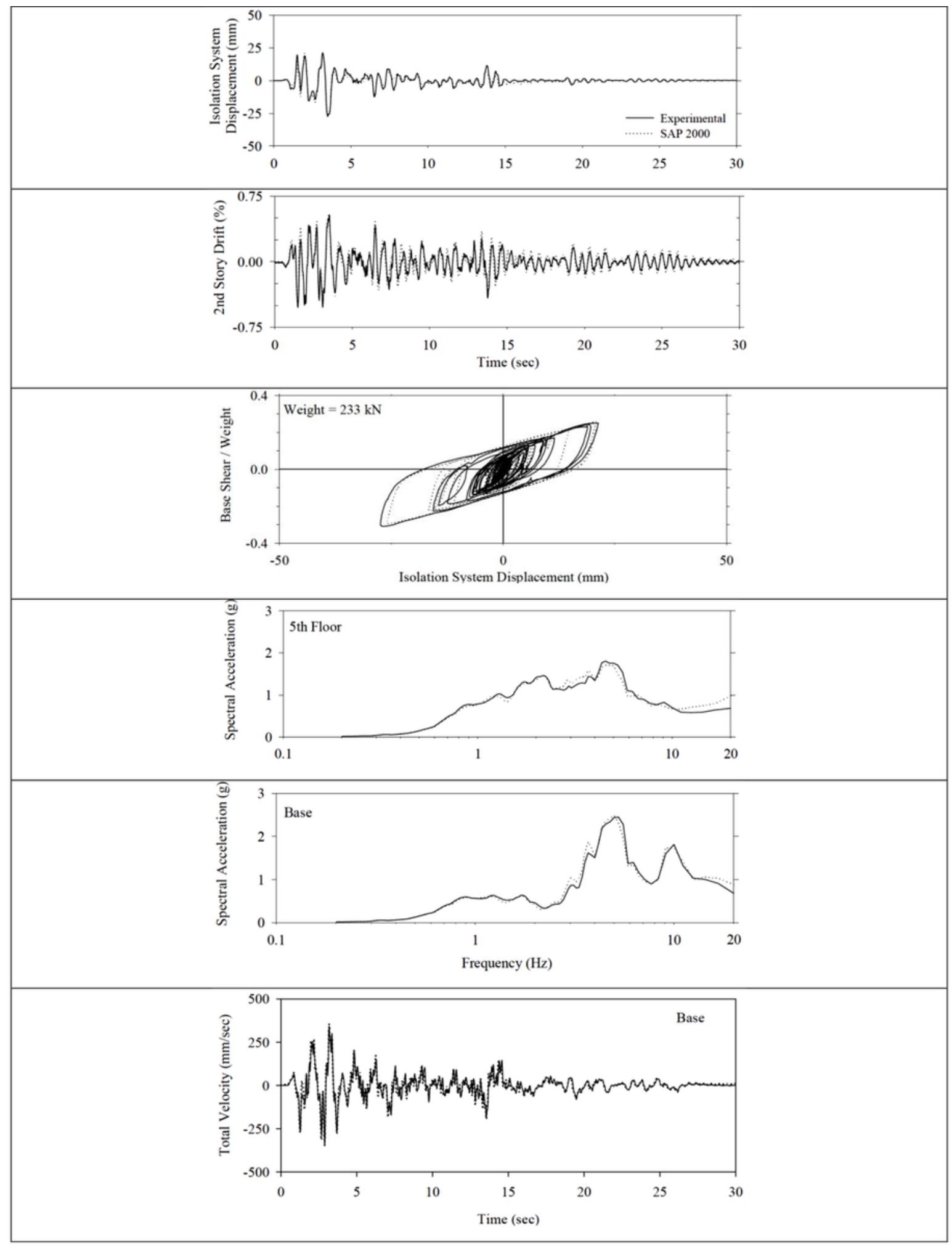

\section{Figure 14}

Comparison of Results for Lead-Rubber System in El Centro 200\% 


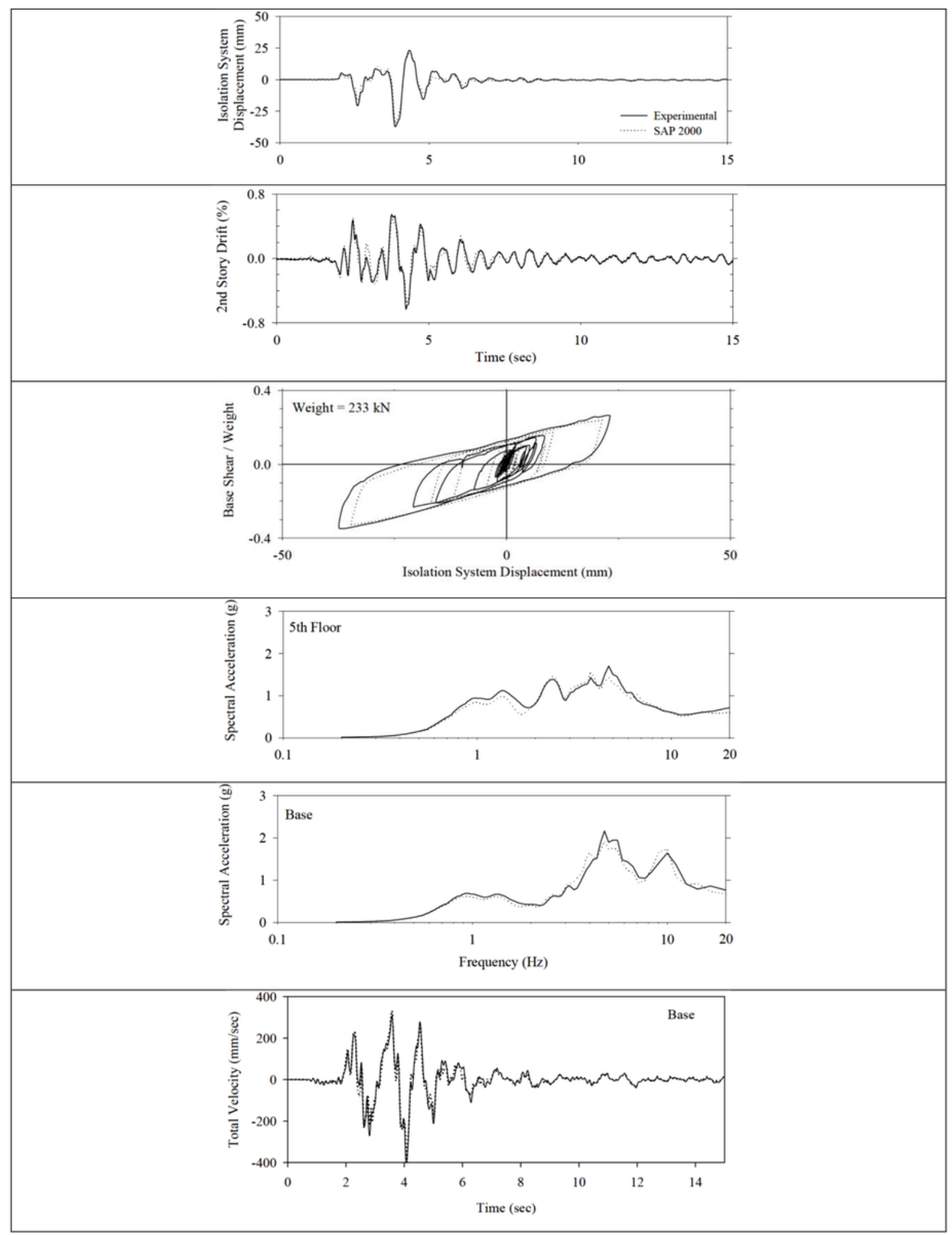

\section{Figure 15}

Comparison of Results for Lead-Rubber System in Sylmar 100\% 